\title{
The Challenges and Opportunities of Honey Production Systems in Jimma Horro District Kellem Wollega Zone, Oromia, Ethiopia
}

\author{
Soresa Shuma ${ }^{1 *}$ and Negasu Gamachu Dinsa ${ }^{2}$ \\ ${ }^{1}$ Dambi Dollo University, Department of Animal and Range Sciences, Ethiopia \\ ${ }^{2}$ Oromia Agricultural Research Institute (IQQO), Haro Sabu Agricultural Research Centre, Ethiopia
}

*Corresponding author: Soresa Shuma, Dambi Dollo University Ethiopia, Department of Animal and Range Sciences, Ethiopia

\section{ARTICLE INFO}

Received: 幽 July 25, 2020

Published: August 04, 2020

Citation: Soresa Shuma, Negasu Gamachu Dinsa. The Challenges and Opportunities of Honey Production Systems in Jimma Horro District Kellem Wollega Zone, Oromia, Ethiopia. Biomed J Sci \& Tech Res 29(2)2020. BJSTR. MS.ID.004779.

\section{ABSTRACT}

The study was designed to identify the challenges and opportunities of honey production systems in the study area. Three peasant associations (PAs), namely Gile, Tibe and Kaba Sayo of Jimma Horro District PAs was selected based on variations in agro-ecology (high land, mid land and low land).Beekeepers in the study are challenged by several honey production Constraints. Such constraints are Honeybee pest and predators, misuse of pesticides and herbicides, honeybee diseases, colony absconding and shortage of bee forages. Some of the opportunities associated with the study area are Availability of honeybee floral resources, Availability of honeybee resource, increasing hive products' demand and Increasing attention and focus from the government.

Keywords: Honey Production; Bee Forage; Challenges; Diseases

\section{Introduction}

Beekeeping or apiculture entails the rearing or keeping of bees with the aim of exploiting its products (such as honey, pollen grain, propolis, and brood) (Onwumere et al). Whereas, Belets Gebremich and Berhanu Gebremedhin reported that apiculture is a promising off farm enterprise, directly and indirectly contributes to smallholders' income in particular and nation's economy in general. In addition, Takele Gina [1] reports indicated that Ethiopia is one of the countries in the continent that has the largest honeybee population and owns a big honey production potential in its varied ecological and climatic zones. Specifically, Ethiopia is the largest and leading honey producer in Africa and tenth largest honey producer in the world. Unlike many other commodities such as crop and livestock, honey products generate multiple market opportunities, and are also nutritious foods. In addition, the production process is not in competition with another form of agriculture and it can be integrated positively (Aravindakshan et al) [2].The same to that, honey production is also considered as a natural resource conserving and environmentally friendly activity [3] through its plant pollination services. Thus, it should be one of the most important intervention areas for sustainable development among poor countries like Ethiopia [4].

Based on the level of technological advancements, three types of beehives (traditional, intermediate and frame hives) are used for honey production in Ethiopia. Despite the long beekeeping tradition in Ethiopia, the highest bee density, being the leading honey producer and one of the largest beeswax exporting countries in Africa, the share of the sub-sector to the Gross Domestic Product (GDP) of the country has never been commensurate with the huge resources and the country's potential for beekeeping. Productivity has always been low, leading to higher domestic hive products utilization and relatively low export earnings. With this, even if efforts are still on-going, most of the on-station based adaptive research works which were carried out for the last few decades couldn't improve hive productivity and honey production so far. However, even if Jimma Horro District is believed to have diversified vegetation, cultivated crops composition and considered as beekeeping potential, a detailed and comprehensive research data on honey production systems, challenges and opportunities in the 
area is not available so far [5] .Therefore, this study was conducted to give an insight into the honey production potential constraints and opportunities in Jimma Horro District, Oromia region, Ethiopia.

Beekeeping by its nature doesn't need huge investment (financial asset), large size of land and complicated technical knowledge. Beekeeping strengths and supports the rural community livelihoods to become less vulnerable to different shocks and avert risks. However, the individual poor beekeeping

Materials and Methods farmers in particular and the country in general still could not harvest honey to the required amount which in turn income from this sector to the producer, trader and the country is generally low in honey. In general, it believes that there are different honey production challenges which couldn't enable the beekeepers to maximize beekeeping outputs. This work, therefore, had tried to magnify and suggest possible solutions against production constraints and identified some major challenges that are obstacles to product maximization in the study area [6].

\section{Study Area}

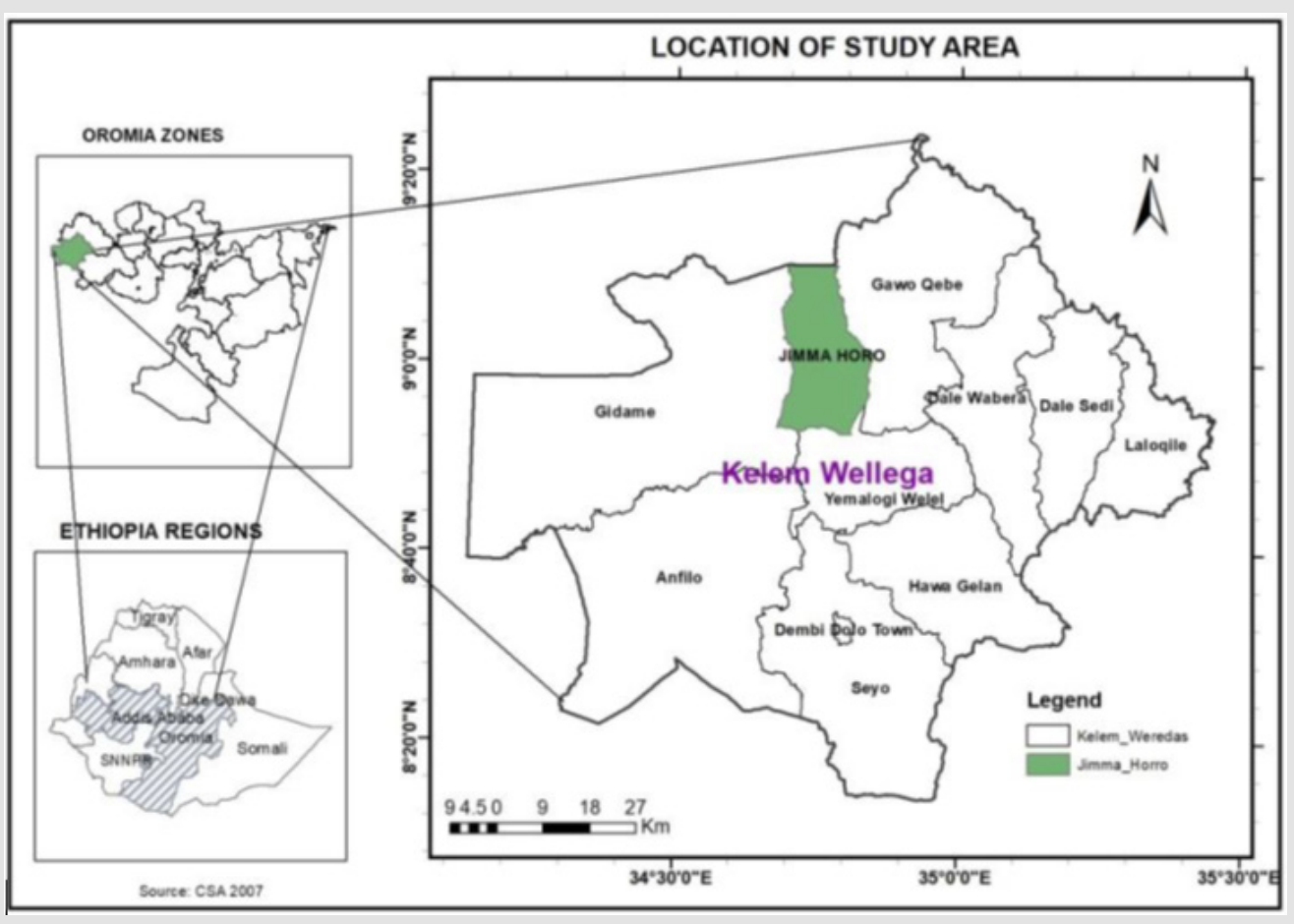

Figure 1: Map of study Area

The study was conducted from September 2018 to December 2019 in three selected peasant associations (Tonfi Cari, Ilu Kitaye and Abono) of Jimma Horro district, Kellem Wollega Zone in Western Ethiopia. This district is bounded by Begi district in North, Gawo Kebe district in East, Yamalogi Wolel district in South and Gidami district in West. The area is located at about $665 \mathrm{~km}$ west of Addis Ababa. The area is located at an elevation of $1400-1830 \mathrm{~m}$ above sea level. The Topography of this district is characterized by Forest of Wolel Mountain and Dati Wolel Park. The main river in this district is Supe, Burar and Kumbabe. The climatic condition alternates with long summer rain fall (June to September), short rainy season (March to May) and winter dry season (December to February). The minimum and maximum annual rain fall and daily temperature range from 800 to $1200 \mathrm{~mm}$ and 15 to $25 \mathrm{oc}$, respectively. Jimma Horro district is characterized by Dega (19.7\%), Woyna dega (48.5\%) and Kola (31.8\%). Livestock population in area is estimated to be about 91671 heads of cattle, 300 mules,
12500 donkeys, 7225 Horses 26650 sheep, 20166 goats and 98271 species of poultry. The farmers in the area practice mixed farming (Figure 1).

\section{Method of Data Collection}

Data essential to the study were collected from secondary sources, undertaking group discussions and formal survey and field observation.

\section{Secondary Data}

The secondary data necessary for the investigation were collected from organizations and PA administrations.

\section{Focus Group Discussions}

Focus group discussions were conducted in the study area with purposively selected community representatives such as: elders are having rich indigenous knowledge in beekeeping, PA leaders, DAs, 
bee experts and women representatives. In order to gain a greater insight into the topics during the formal survey and to validate or check the data collected. Each of the focus group discussion consisted of 10 to 21 individuals and 3 group discussions were undertaken in the study area (one in each altitude zone).

\section{Formal Survey}

A formal survey was conducted using structured questionnaire, with open-ended and closed-ended questionnaires with the help of trained enumerators. Potential, challenges and opportunities of beekeeping in the area: harvesting time, dearth period and amount of honey harvested, honey storage facilities, honey selling situation, potential honeybee plants and flowering time, poisonous plants, water resources availability, honeybee pests and predators, herbicides, insecticides and other chemicals applications have been collected.

\section{Data Analysis}

The statistical analysis used in the study varied depending on the type of variables and information required. Descriptive statistics such as means, standard deviation, frequency and percentages was used to analyze the quantitative data using SPSS version 23 software were mainly applied.

\section{Results and Discussions}

\section{Demographic and Socio-Economic Characteristics}

The demographic characteristics beekeepers were summarized in terms of gender, marital status and age, education level.

\section{Gender of the Respondent}

Out of the total respondents, about 30\% in the high land, $40 \%$ in the mid land and $20.3 \%$ in the low land were males, whereas $3.5 \%$ in high land $\% 5.7$ in the mid land and $0.5 \%$ in the low land were females.

\section{Marital status of the respondent}

Table 1: Respondents by Gender.

\begin{tabular}{|c|c|c|c|}
\hline \multirow{2}{*}{ Variables } & \multicolumn{3}{|c|}{ Altitude } \\
\cline { 2 - 4 } & High land & Mid land & Low land \\
\hline \multicolumn{3}{|c|}{ Gender } \\
\hline Male & 30 & 40 & 20.3 \\
\hline Female & 3.5 & 5.7 & 0.5 \\
\hline
\end{tabular}

Marital status of the sample respondents indicated that about $34.6 \%$ in the high land, $43.8 \%$ in the mid land and26.4\% in the low land was married. Whereas $1.8 \%$ in the high land, 3.2 in mid land $1.2 \%$ while in the low land was single respondents. The average family size of the sample farmers in the study area was 5.32 persons, with maximum and minimum family size of 9 and 2 person, respectively. This variable can indicate the food needs and competition for resources available. This difference is dealt to be insignificant as consulted from the test statistics. The beekeepers had an average experience of 15.4 years ranges from 1 to 30 years (Table 1).

The level of beekeepers' experience was taken to be the number of years that an individual was continuously engaged in beekeeping. This is what one would expect in a situation where people are actively engaged starting from an early age in helping older beekeepers to undertake basic asks. Based on this exposure, young people gradually move on to become independent beekeepers as soon as they obtain their own hives (Gichora, 2003). They continue accumulating experience by seeking technical advice from fellow beekeepers whenever necessary. The mean age of the respondents were (40years) ranging from 26 to 49years (Table 2). This result showed that beekeeping can be performed by economically active age groups and in most cases people at younger and old age is actively engaged in beekeeping activities. Of the total households interviewed, $93.8 \%$ are married while 5\%, 1.2\% are single, divorced, respectively. With regard to religion, all of the household respondents 50.7, 27.1, 22.2) are Protestant, Orthodox and Muslim respectively. Based on the results of this study, people regardless of their marital status undertake beekeeping activities in the district (Table 3).

Table 2: Marital status of Respondents

\begin{tabular}{|c|c|c|c|}
\hline \multirow{2}{*}{ Variables } & \multicolumn{3}{|c|}{ Altitude } \\
\cline { 2 - 4 } & High land & Mid land & Low land \\
\hline \multicolumn{4}{|c|}{ Marital status } \\
\hline Married & 34.6 & 43.8 & 26.4 \\
\hline Single & 1.8 & 3.2 & 1.2 \\
\hline
\end{tabular}

Table 3: Age, experience, family size and land holding of household heads.

\begin{tabular}{|c|c|c|c|c|}
\hline $\begin{array}{c}\text { Socio economic } \\
\text { indicators }\end{array}$ & Minimum & Maximum & Mean & S.D \\
\hline Age of household (yrs.) & 26 & 49 & 40 & 4.86 \\
\hline Experience (yrs.) & 1 & 30 & 15.4 & 1.97 \\
\hline Family size & 2 & 9 & 5.32 & 1.97 \\
\hline Land holding (ha) & 2 & 4 & 2.97 & 0.83 \\
\hline
\end{tabular}

\section{Land Holding}

The average land (plowing, backyard and pasture) holding of the sample respondents during the study year was 2.97 hectares (Table 1) which is higher than the National average household landholding of 1.0 - 1.5 hectares.

\section{Educational status of the Family Heads}

Regarding educational status, among the sample respondents $9 \%$ had not received any education, while 38.9\% percent could only read and write. The rest were at stages of literacy ranging from elementary to high school level. More specifically, 35.4\% and $16.7 \%$ of the sample respondents had attended elementary school, and secondary and high school (Table 4). Gichora (2003) noted that for more advanced beekeeping, one should have a good grasp of 
bee biology and behavior of bees for better colony management. Moreover, for illiterate people there is a need of intensive training and persuading of beekeepers before distributing movable frame hives. Therefore, according to the result of this study the high level of illiteracy $(9 \%)$ in the district limits the effectiveness of formal training programs and requires more emphasis to be placed on practical demonstration of essential concepts especially in improved beekeeping.

Table 4: Educational Status of the Head of the Household.

\begin{tabular}{|c|c|c|}
\hline & Total sample $(\mathbf{n}=\mathbf{1 4 4})$ & \\
\hline Educational Status & $\mathbf{N}$ & $\mathbf{\%}$ \\
\hline Illiterate & 13 & 9 \\
\hline Read and Write & 56 & 38.9 \\
\hline Elementary & 51 & 35.4 \\
\hline High School & 24 & 16.7 \\
\hline
\end{tabular}

\section{Challenges and Opportunities of Honey Production Systems in the Study Area}

\section{Challenges of Honey Production Systems in the Study Area}

Beekeepers in the study area are challenged by several honey production constraints. Beekeepers have also understood that colony number in their respective area is decreasing from time to time. However, in order to utilize outputs from the beekeeping sub- sector, identifying and characterizing the existing challenges and looking for possible solutions shall take a significant priority in the area. Accordingly, respondent beekeepers have identified the following major challenges which they want to have immediate interventions.

\section{Poisoning of Honeybees}

The beekeepers were asked whether their bees get incidence of poisoning or not. Accordingly, $93.6 \%$ of the respondents replied positively. According to the sample respondents $98.6 \%$ of the bees poisoning occur due to agro chemicals mainly insecticides and herbicides, whereas $1.4 \%$ of the case occurs due to poisoning from plants like Bisan (Croton macrostachys), Semiza(Justitiaschemperina), Gerawa (Venonia spp),Toto hareg (salanecio angertus), Kulkual (Euphorbia spp,Legeta (Grewia ferruginea) and Donga (Apodytes dimidiate). However, these need to be confirmed by research. Honeybees can be poisoned by chemicals and poisonous plants. The chemicals used for crop protection are the main pesticides that kill the bees. The use of chemicals and pesticides for crop pests', weeds, Tsetse fly, malaria and house pests control brings in to focus the real possibility of damaging the delicate equilibrium in the colony, as well as contamination of hive products. To control poisoning by chemicals, nearly $21.2 \%$ of respondents use chemicals far from apiary, $15.4 \%$ use hand weeding, $2 \%$ close the hive entrance during application, $5.4 \%$ adjust time of chemical application and 56\% do not use any control measures for chemical poisoning. So strategies for chemical poisoning from the regional government should be very important. Nectar or pollen of poisonous plants was reported to be toxic to the bees themselves, and those in which the honey produced from their nectar are toxicto humans. Removing those poisoning plants around apiary and developing improved and local bee forage species is the solution.

\section{Honeybee Pests, Predators and Diseases}

Respondents were asked to identify honeybee diseases and major pests. Based on the result of this study, the existence of pests was a major challenge to the honeybees and beekeepers. After having identified the major pests facing the beekeeping activities, farmers were requested to rank them and the result indicated that Hamagot /shelemetmat/, wax moth, ants), and snake were the most harmful pests in order of decreasing importance. Based on the results of this survey, $65 \%$ of sample respondents had observed honeybee diseases in their hive. The perception of the beekeepers in the formation of worms due to disease has had probably happen due to lack of knowledge of differentiating the damage caused by honeybee diseases and larvae of wax moth. The latter is known to affect the bee's comb through its larvae with which the beekeepers get confused worms formed due to disease (Table 5). Besides to identifications, beekeepers of the Jimma Horro district have serious concern and have rich experience and various practices in controlling some of the honeybee pests (Table 6).

Table 5: Percent and ranks of major pests and predators

\begin{tabular}{|c|c|c|}
\hline Major pest and predator & \% & Rank \\
\hline Ants & 8.6 & 2 \\
\hline Wax moth & 22.8 & 5 \\
\hline Bee lice & 6.2 & 4 \\
\hline Beetles & 6.4 & 7 \\
\hline Spiders & 2.4 & 6 \\
\hline Wasps & 3.2 & 9 \\
\hline Prey mantis & 1.6 & 8 \\
\hline Lizard & 2.3 & 11 \\
\hline Snake & 1.2 & 12 \\
\hline Monkey & 0.7 & 1 \\
\hline Birds & 1.3 & \\
\hline Hamagot /shelemetmat/ & 43.3 & \\
\hline Total & 100 & \\
\hline
\end{tabular}


Table 6: Major enemies of bees in Jimma Horro district as ranked by respondents and preventive measures.

\begin{tabular}{|c|c|}
\hline Ants & $\begin{array}{c}\text { Clean apiary, Place fresh ash and urea fertilizer around the base of a hive stand, Plastering hives stands with mud, spraying } \\
\text { garlic juice, malatin and hot water, burning the ants with fire, destroying ants nests, use of white eucalyptus leaves as repellant, } \\
\text { plastering of thin rubber sheets and metals between the hive and hive stands, pour used engine oil around the hive stand and } \\
\text { keeping weeds well away from the base of the hive stand. }\end{array}$ \\
\hline Wax moth & $\begin{array}{c}\text { Clean apiary, remove old comb, and strengthen the colony, fumigation with cotton cloth and sorghum bran, rubbing with } \\
\text { recommended plant materials like Vernonia amygdalina, spraying garlic juice. }\end{array}$ \\
\hline Bee lice & Clean apiary, fumigate with Olea Africana and cigarette and sorghum bran and make the colony strong. \\
\hline Beetles & Clean apiary, narrowing the hive entrance, hand picking and kill, cover r opening of hive. \\
\hline Spiders & Clean apiary, removal of spider's web and killing. \\
\hline Wasps & Clean apiary \\
\hline Prey mantis & Cleaning apiary \\
\hline Lizard & Clean apiary, use spin around and kill \\
\hline Snake & Clean apiary, smoking with plant material and kill \\
\hline Birds & Use spin, killing, fencing and chasing with dogs \\
\hline Hamagot &
\end{tabular}

\section{Honeybee Diseases}

As we know, honeybee diseases are causing a significant effect on the health status and well-being of the honeybees. Even if they couldn't identify the common name of the disease and which is, $12.5 \%$ in the high land and $13.6 \%$ in the mid land and $6.2 \%$ in the low land areas of the respondent beekeepers have confirmed the presence of honeybee disease in their apiaries and can be detected once in a while. As the beekeepers respond the sign of the disease such as bees fail to fly, crown on the ground in front of hive, we probably say that these disease called virus. Fortunately, the most important brood and adult bee diseases (like the American and European foul brood diseases and some major viral diseases) nominated as killers of a colony have not been identified in the country in general and in the study area in particular. To know and control the disease from the study area the government should take the measurements such as identifications of the disease, means of transmission, season of prevalence and by what method it controlled.

\section{Colony Absconding}

As one of the major problems in beekeeping, colony absconding was identified by only about $2.4 \%$ in the highland $7.5 \%$ in the mid land and $8.6 \%$ in the low land of respondent beekeepers. In addition, they have explained that colony absconding is happening at any time of the year regardless of the hive types because of continues colony disturbances from different factors in which pest infestation is the most common cause. Off course, this has been also a self-explanatory problem happening because the majority of the beekeepers are not inspecting their colonies frequently. This is also because; most local beekeepers believed that opening colonies in any time of the year will increase absconding which needs to be changed. As a suggestion beekeepers should have always follow their bee hives to know, the colony problem and control it from bee enemies. Seasonal management such as feeding in dearth period, follow after transferring, reducing the space/super, were essential for transitional and frame hives.

\section{Shortage of Bee Forages}

Like other living organisms, honeybees need adequate nectar and pollen to survive, reproduce and honey production. Moreover, as the presence of bee forages varied from place to place and all plants are not equally important for bees in supplying both nectar and pollen resources, it should be understood that honey plants are home for bees and provide basic nutritional requirements for the survival and reproduction of honeybees.

However, currently, misuse of honey and pollen source plants in the environment through significant deforestation has brought about shortage of bee forages endangering life on earth in general and in the study area in particular. In this case, even if only $4.4 \%$ in the high land and $7.3 \%$ in the midland of respondent beekeepers do understand shortage of bee forage is a problem in their respective localities, this problem has been pronounced to be a nationwide most important problem endangering the beekeeping sub sector. However, very few beekeepers from each of the sampled (agroecology) explained that they are working on bee forage development around their apiaries. Though honeybees support the humankind through their immense pollination services in various agricultural crops, the role of honeybees in this regard is less understood by the local community in particular and among the country's farming community at large. Thus, this indispensable service from the honeybees in our agricultural economy, we strongly suggest, should be pronounced to encourage farmers for sustainable use of plant resources and their pollinators.

\section{Opportunities of Honey Production Systems in the Study Area}

Some of the opportunities associated with the study area and described by the respondent beekeepers are presented below:- 


\section{Availability of Honeybee Floral Resources}

As a matter of fact, the country at large and the study area in particular have been described as rich in floral resources (data from Jimma Horro Livestock Agency). The availability of multipurpose trees and shrubs in the study area has been identified not only as major sources of pollen and nectar for honeybees but also provide different services to the community. Of course, the interdependency between honeybees and floral resources also enables the reproduction, productivity and diversification of plants on earth. Very recently, establishment of apiaries near a forest, closure and religious areas is a common practice in the study area. That is, we believe, because of the fact that beekeeping farmers have understood the values of floral resources for increased honey production and survival rate of the honeybee colonies.

\section{Availability of Honeybee Resource}

To start beekeeping; one person must find the colony by any means which is simple way to him/her. From all methods of catching swarm, obtaining from the environment is more advantageous than the other methods because it does not incur cost, and one can catch several colonies in one season. In the study area, most beekeepers start beekeeping by catching the swarm from the environment and following by gift from their parents and also from their relatives. This explains the environment has good access to honeybee resource.

\section{Increasing Attention and Focus from the Government}

To strength the apiculture sector and to produce the hive products and benefit from the activities of honeybees the attention of government is very important. Now days the government of Ethiopia focused on the apiculture sector by interconnection with natural resource conservation. In the study area, both government and non -government organizations undertake many activities in the form of training and helping the top beekeepers by providing them some modern beehive.

\section{Increasing hive products' demand}

The rising of hive product is depending on many reasons:management, floral resource, knowledge of honey flow period and so on. To increase the hive products, one beekeeper should update his/her knowledge by working many years with honeybee and have technology training from government and non-government organizations. From the study area, the production of honey increased from the year to the year because of increased intensity and frequency of giving training in the area.

\section{Conclusion and Recommendation}

Honey production in the study area has been faced with multiple constraints (the effect of agro chemicals application on crops, pest and predators, bee disease, absconding, shortage of bee forage, shortage of water, absence of market center) but study area has a lot of opportunities (availability of bee flora, honeybee resource, attention and focus from the government and nongovernment). From this study the following recommendations can be prepared for the present and future works in apiculture sub sector in the study area. To spray applications such as pesticides especially on crops, it is first important to evaluate the time of application in such a way that it does not have an effect on the bees. The effect of wax moth is difficult to control by beekeepers hence, the method which is approved for this pest is that all hives which have wax moth are removing and melted the infested comb and making the new foundation sheet should be addressed and supported by government and non-government $[7,8]$.

\section{References}

1. Takele Gina (2014) Potential of Honey Production and its Utilization for Food Security in Filtu Woreda, Liben Zone, Somali Regional State Ethiopia 14(9): 863-865.

2. Gallmann P, Thomas H (2012) Beekeeping and honey production in south western Ethiopia. Ethiopia: Honeybee investigation.

3. Gidey Yirga, Teferi Mekonen (2010) Participatory technology and constraints assessment to improve the livelihood of beekeepers in Tigray Region, northern Ethiopia. Momona Ethiopian Journal of Science 2(1): 76-92.

4. Gibbon P (2001) Agro-Commodity Chains: An Introduction. Wiley Online Library.

5. Workneh Abebe (2011) Identification and documentation of indigenous knowledge of beekeeping practices inselected districts of Ethiopia. Journal of Agricultural Extension and Rural Development 3(5): 82-87.

6. Atsbaha Haile Mariam, Taye Tolemariam, Kebede Debele (2015) Assessment production system, constraints and opportunities in three selected Woredas of Tigray Region Ethiopia Basic Research Journal 4(10): 304-315.

7. (2004) Beekeeping Training M2003anual, HBRC Holeta Ethiopia.

8. Fikre Girma, Tarun kumar Raghunvanshi, Tenalem, Ayenew, Trufat Hailemariam (2015) Landslide hazardzonation in Ada Berga district, Centeral Ethiopia- AGIS Based Statistical Approach. 
ISSN: 2574-1241

DOI: 10.26717/BJSTR.2020.29.004779

Soresa Shuma. Biomed J Sci \& Tech Res

(C) (P) This work is licensed under Creative Submission Link: https://biomedres.us/submit-manuscript.php

$\begin{array}{ll}\text { BIOMEDICAL } & \text { Assets of Publishing with us } \\ \text { RESEARCHES } & \text { - Global archiving of articles } \\ \text { - Immediate, unrestricted online access }\end{array}$

